\title{
Gender Role Commodification by the Wedding Industry
}

\section{Sanastri Nurdityaning Dewandaru ${ }^{1, *}$ Endah Triastuti ${ }^{2}$}

\author{
${ }^{1}$ Universitas Indonesia \\ ${ }^{2}$ Universitas Indonesia \\ *Corresponding author. Email: sanastridewandaru@gmail.com
}

\begin{abstract}
Women have for decades been socio-culturally constructed as an object of the institution of marriage. The media has played a major part in constructing an ideal of femininity portrayed through the narrative of a bride. This glorified image of a perfect bride later postulated marriage to be a fit state for the fulfillment of women and as a tribute to femininity. This paper purposes to critically analyze the manner in which the media commodifies gender roles to promote both the institution of marriage and the wedding industry as a whole. This conceptual paper is compiled on the basis of relevant literature and examines ideas related to gender roles and marriage. The paper contemplates studies conducted by Boden (2001), Engstrom (2008), Chang (2015) and Parker (2016) to unveil a phenomenon that appears simple but exerts an enormous social, economic, and cultural impact. It is found that heterosexual relationships and marriage imply the subordination of women to men through the accomplishment of prescribed stereotypes and social roles. This paper is expected to expand the awareness of the extended implications of the wedding industry in Indonesia.
\end{abstract}

Keywords: Social Construction, Gender Role, Commodification, Weddings

\section{INTRODUCTION}

Technological development and the resulting expansion of the communications industry expose many people to an abundance of messages that affect society's values, norms, beliefs, and perceptions (Brodie, 2004). The media now plays a pivotal role in constructing identities, to the point of defining what it means to be a proper male or female person (Jerusaem, 1983; Adoni, H., 1984). The communications industry produces commodified meaning through media texts and segments people into varied rigid social configurations including gender and class. Put differently, media are now central to the ultimate representation of the social realities of people (Brooks and Hébert, 2006).

The media perpetuate images emphasizing the innate decorative and functional roles of "ideal" womanhood (Van Zoonen, 1994). They play a major part in the construction of certain stereotypes of femininity to fulfill the structural needs of a patriarchal and capitalist society by reinforcing gender differences and inequalities (Stonim and Gur-Yaish, 2015; Ibid, 2015; Camp, 2001). The recently segmented media industry circulates the "ultimate" pleasure of womanliness through highly profile wedding magazines replete with images that glorify stereotypes of the ideal bride: she is pure, perfect, sacred, and feminine. At the same time, media discourse also implants negative stereotypes of unmarried women as half human, unhappy, cursed, and immoral (Parker et al., 2016a; Chang, 2015). Women are expected to marry to fit into the model proposed by this media tribute to weddings and brides.

Among other effects, practices or beliefs glorifying marriage are strengthened through this underlining of the feminine perspective. Hence, the negative stereotypes of unmarried women emerge because they do not seem to share the prevalent cultural belief in the importance of marriage and are perceived to threaten the status quo.

Many extant studies have investigated the sociocultural construction of gender roles. However, only a few have specifically discussed the commodification of women by media related to marriage and wedding consumption. Therefore, this paper intends to utilize the literature review method to critically unveil the mediaconstructed hegemonic message highlighting the portrayal of an ideal of womanhood that connects social 
roles and marital status. The results of this study may be used as a basis for future research initiatives.

\section{LITERATURE REVIEW}

\subsection{The Roles of Women and Patriarchal Stereotypes}

The word "patriarchy" was originally used to describe a specific type of male-dominated family system (Bhasin, 2006). The word was later adopted to signify a maledominated social structure. The patriarchal ideology exaggerates the biological differences between men and women and ensures that men are always accorded the dominant roles and that women are always allocated subordinate or feminine social functions (Sultana, 2011a).

Male domination has been established through patriarchal societies over a long historical process across civilizations. For instance, in Victorian England, an era that spanned most of the nineteenth and the early part of the twentieth century, patriarchy was projected through the cult of domesticity (Bauer and Ritt, 1979). The attending images of men and women exemplifying this paradigm recurred persistently in Victorian literature, art, and social commentary. This era distinguished two significant life arenas: the public sphere that included the activities of business, politics, and the professions and was meant exclusively for men; and the private sphere of the home which was demarcated for women and conscripted the space of love and family values (Sultana, 2011b). Although the private sphere was notably referenced as the "woman's world," male domination applied to both domains and women were comprehensively submitted to male authority. Consequently, power over family, society, and the state remained entirely in the hands of men (Jorgensen-Earp, 1990).

Eventually, women were accorded no place in a patriarchal society that did not depend on the existence of men. True womanhood came to be portrayed by the fundamental parable of the perfect lady, a woman submissive to the patriarch and conforming to the social virtue of a successful marriage (Read about the 'hegemonic' group (the un-stigmatized people) are what society projected as 'Normal' and the stigmatized people are the 'minorities' for their characteristic that disqualify them as 'Normal'. Goffman Erving, 1963). In contrast, a woman who did not exemplify the virtues of the perfect lady was negatively stereotyped as a fallen or redundant woman.

For the heuristic purposes of this paper, and to provide a historical overview of the stereotypes to which women were subjected in Victorian England, those "who broke the family circle, be she prostitute, adulterer or divorcee, threatened society's very fabric" (Cominos, 1972) were labeled fallen women. Meanwhile, females who were unmarried, or who took on professions were considered redundant women because the basis of a woman's life, her training, her fulfillment, and her functions was the model of marriage and motherhood. By not obtaining a husband (spinsterhood), a woman was assumed to have failed in securing her livelihood and her raison d'etre (Eliza Warren, 1865).

This cult of domesticity, developed through history, also reigns supreme in current patriarchal societies domesticity. The stereotype of the home being a woman's world is still applied in many cultures, causing the stigmatization of unmarried women (both divorcees and single females) as failed women who are unable to attain a state of normality (Eagly and Steffen, 1984). This stigma eventually affects social beliefs on marriage as illustrated by the media.

Unmarried women are divided into two main categories: those who remain single by choices (both divorcees and unmarried females) or those who become single because of circumstances (widows). Both the classifications of the state of being unmarried are regarded and vilified and are discriminated against to varying extents according to which women internalize the stigma (Parker et al., 2016b). Divorcees are the most negatively stereotyped because they are assumed to have failed in sustaining their marriage. Field research conducted in Bandung, Indonesia demonstrated that women try to avoid divorce as much as possible because of the disgrace attached to the condition. The dishonor that attaches to a divorced woman is associated both with her social and economic status and with her sexuality. Most women are likely to remain in an unhappy marriage to avoid the condition of being divorced (van Bruinessen, 1988).

The status of widowhood is less stigmatized because there it does not carry the shame of a "failed" marriage. Nonetheless, a widowed woman may still be suspect in terms of her sexual, and thus, moral, impropriety (Parker et al., 2015a). Widows are characterized as "un-tamed" unless they are brought under the purview of other men in her family. Since they have been married, it is presumed that they have developed sexual appetites and that they are theoretically free to express their lust once they regain the status of becoming "single." Ethnographic research on men and women's experiences of marriage evidences that divorced women and widows bear a much heavier burden of stigma than men who face the same circumstances. This onus is related to the women being sexually experienced and unattached; it also emanates from the gendered understanding of sexuality (2015).

Differing degrees of stigmatization also apply to women who choose to stay single. They are perceived as less extraverted, conscientious, agreeable, sociable, physically attractive, and satisfied with their lives than coupled women. Greitemeyer's study (2009) also reports 
that single women are perceived as lonelier and as having lower self-esteem than partnered females (Slonim, 2015).

Overall, domesticity still offers the highest social "status" for women. Even though career women are nowadays more common and may be observed to appear in many media discourses, their narratives are often described as a secondary option. Thus, unless there are domestic obligations that cause them to sacrifice marriage in favor of a career, women are encouraged to prioritize the domestic role of a wife or mother.

The circumstance of being a once-married woman who is rendered single by virtue of death or divorce is anomalous in patriarchal societies and constitutes a deviation from the norm. These women are not seen as contributing to the core fabric of society. This double standard applies exclusively to women as divorced or widowed men are not burdened with the same stigma (Parker et al., 2015b). Women develop strategies to avoid such stigmatization and deploy their social, cultural, and symbolic capital in the exercise of agency. One such way is to subscribe to the model of being married solely to fit social attributions of womanhood (purity, sacredness, femininity).

\subsection{Hegemonic Messages on Weddings, Gender Roles, and Consumption in the Media}

Most people view the media from an audience (consumer) perspective and often forget that the media are part of an industry. The media industry is, in fact, organized around the process of production, distribution, and consumption just like any other. It is thus pertinent to conduct an intertextual analysis of media outputs.

According to Carragee (1993), hegemony is a necessary theoretical perspective from which to examine media content, and particularly in the evaluation of how media outputs are produced (Carragee, 1993). The perfect day is a term often used by bridal media to exaggerate social expectations from weddings. In addition, celebrity weddings and the visuals provided by Hollywood films add to the media-presented hegemonic messages (Gibbons, 2003)

In sum, bridal magazines and the portrayal of lavish weddings across media channels put forth the message that weddings serve as the endpoint of romantic relationships and that they are the life goal of women. As such, the bridal media serve as an example of hegemony, a key term that was conceived by Antonio Gramsci and later defined by Landy (1994) as the exercise of indirect power as exemplified by civil institutions, among which he includes the media industry (Landy, 1994).

\subsection{Contextualizing the Bride As a Commodity}

"Every bride dreams of being

a princess on her wedding day."

As illustrated by the above statement, the term "princess" is used repeatedly in the media as brides become objects of their own gaze (Engstrom, 2008). Most people now associate princesses with the narratives presented by Disney animated feature films (Heatwole, 2016). Considering the implications of the longevity of the simplistic princess storyline, Jeanne Dubino alluded to the Cinderella complex in 1993. This construct drives women to cultivate domesticity and beauty above all else in hopes of achieving future romantic bliss. Further, it encourages the broad cultural belief that such domesticity is a valid life goal for women.

In Otness's opinion (2003). the Cinderella myth often symbolizes a woman's "success" in social terms, because she improves her social status by being rescued from a poor environment by a prince. Once locked in the circumstances of domestic abuse by her stepmother and two step sisters, Cinderella is granted the title of a princess. The fairy tale wedding is thus cultivated by the folklore, which becomes the central image for the romantic version of that culture. The belief that the moment she marries the prince constitutes Cinderella's reward for her labor, her innocence, her goodness, and her obedience to her domestic tasks is cultivated by the myriad ways in which the modern versions of the Cinderella syndrome are presented to media audiences. These ideas become embedded through narratives that sell a once upon a time that ends with a happily ever after (Otnes and Pleck, 2003a).

In popular media narratives, the bride is the perfect portraiture of womanhood and femininity: a pure, delicate, object of beauty that is transformed by the "magical" bridal sacraments: the white wedding gown, the veil, the make-up and hair, and the bouquet (Shunatona, 2019; Johnson, 2018). Discrete philosophies supposedly associated with the unique personality of every bride are embodied by the etiquettes that apply to bridal make-up or accessories. A sense of familiarity with this image is bred into women who strive to achieve a particular resemblance that truly represents the identity they would like to achieve as a bride.

An overview of an ideally mediated and constructed concept of a bride is repeatedly confirmed and assured as a standard of how women should represent themselves. The wedding and its surrounding fantasy become for women the much-touted highlight of their lives, something to yearn for and to value because after that one, special day, they must return to a domestic world that comprises their familiar and monotonous tasks. This duality of the bridal role, as created and imaged in wedding media serves to exemplify Felski's (2000: 82- 
83) contention: "Femininity is formed through mass production and mass reproduction, disseminated through endless images of female glamour and female domesticity" (Felski, 2000).

Engstorm (2008) concludes her research on unraveling The Knot's hegemony by asserting that as the "producers" of this major event, brides must always be in control; they must direct all the action and ensure the high quality of all aspects of the wedding ceremony and reception. The Knot's online platform and television programming reinforce to viewers that weddings belong to the feminine realm in which the bride is required to take control and to enforce her vision at all times (Boden, 2001a).

\subsection{The Wedding Fantasy: Re-enhancement, Objectification and Transformation}

The media symbolize brides through three key elements: the wedding dress, the special application of cosmetics, and the hairstyling (Engstrom, 2008). Boden (2003) refers to the constructed idea of bridal appearance through make-up, hairstyling, dress, and accessories as a type of work or production that now depends upon the skills and proficiencies of industry professionals (Boden, 2001b). Brides who describe months of effort put into pre-wedding dieting and beautification willingly delegate and relinquish control over the bridal appearance at this penultimate stage to other, more experienced parties such as hairdressers, beauticians, and make-up artists. These professionals offer as much transformation as is needed to uplift and accentuate a mere woman to fit the standard of being a bride.

The wedding experience is itself a product of the recreation of a real-life fairytale. Consumer culture takes the human longing for love and packages it as a longing for goods, services, and experiences that express love. In fairy tales, the wishes of characters are fulfilled through magical interventions. In the world of consumer culture, people acquire their magic through the purchase of goods, services, and unique experiences (Otnes and Pleck, 2003b).

Transformation is a crucial part of the hegemonic media messages on weddings. It is perceived as the process of a woman objectifying or "commodifying" herself as the bride. This consumption-based construction of the bride as a fantasy "object" of admiration for the wedding party and also for herself causes a continued self-consciousness of her position as the unequivocal center of attention for the whole day. This selfconsciousness is most intensely in the early stages of the wedding ceremony which represent the first close public scrutiny of the objectified bride. For most people, the wedding is a visually familiar ritual; for those actually being wed, this familiarity seems to contradict the strangeness of their own participation as the central actors of the proceedings (Boden, 2001c).

\subsection{The Bride as a Star}

As a reward for her adherence to the hegemony of femininity, women are rewarded by the temporary status of being celebrities. The one day in which a woman, any woman, can be a star is her wedding day (Long and Wall). Boden states that overwhelmingly, femininity is conceptualized as "picture-perfect," visual that triggers pleasure in the bride as well as in her audience for the observance of the cultural requirements of obtaining a successfully bridal appearance (Engstorm, 2008).

Long and Wall (2011) explain that the notion of media "stars" must be understood primarily as commodities "produced" for a profit motive by media companies for the consumption of audiences. Usually, the term star or celebrity are used for actors or performers in the entertainment industry. Gledhill (1991) affirms: "Actors become stars when their off-screen lifestyles and personalities equal or surpass acting ability in importance" (Gledhill, 1991). Stars exist across a wide spectrum of texts and the images they acquire accompany them to all the part that they play and in all situation in which they find themselves in other media forms. It may be contended that the term "star" can only be conferred on a film actor or on a singer in a band; however, the expression has developed to also apply to other contexts that imply a person becoming the cynosure of all eyes, as has been used in this study.

In order to play a "perfect" part as a temporary celebrity, women go to great lengths to mold themselves through intense pre-wedding rituals: they practice unhealthy and extreme diets and avail of expensive spa, face, and hair treatment routines. If a "wedding" is likened to a movie, then the bride performs the role of its protagonist: she is the celebrity playing a role or starring in the film. As the star, the bride's image must be carefully constructed within and without to capture the sense of "star-power." Boden suggests that stars are important identification figures for consumers (women). In order to identify with a star, audiences must therefore find points of contact. A star must represent the experience of what it is to be associated with stardom in some way.

\subsection{The Commodification and Consumption of Weddings}

Above all, the notion of consumption reveals human relations with material objects: the associations between shoppers and the products or services they buy; connections between and individual and society, the consumer and the market; personal and cultural engagements with the imagination, the body and identity; and relations of gender, age, class and "race" (Boden, 
2001d). According to Gibbons (2003), the annual capital earned by the wedding industry in the UK is estimated at between $\$ 50$ and $\$ 70$ billion. The potential for this market is immense: around 2.4 million marriages are performed each year (Gibbons, 2003b). Engstorm (2008) asserts that the investment of money and time on a traditional wedding is significant; the average "big" wedding costs around $\$ 20,000$. Weddings are thus major events that also signify a major expense for those beginning life as a married couple. More than half the couples who choose to celebrate their wedding pay for it all themselves, and begin their married life in debt (Currie, 1993) (Engstorm, 2008b).

The role of women in society has clearly undergone a process of commodification.; Kosut (2006) asserts that cultural and social commodities are purchased as embodied status symbols and are also used to sell other commodities (Kosut, 2006). Domesticity is portrayed for women through media discourses as a "natural" and inborn trait and thus, is innately the purpose of women's existence in society. The prevalence of feminine women in society indicates that being feminine holds mass appeal.

When this domestic role adopted by women (feminine, maternal, being married) is commercialized through the transformation of its use value to its exchange value (or commodified), the domestic role of women becomes a marketable product that has an exchange value that "sells." An already constructed reality of a woman's role of being married is often perceived as an objective reality (what the world perceives as right or fact) that is primary for her. Objective reality then symbolized through the construction of the "bride" is represented by media and fused into the subjective reality of women. This paper contends that the endless cycle of transforming use value to exchange value contributes to the manner in which women objectify themselves to satisfy their needs of being included in an objective reality (being a bride, being married) and lead to Bocock's (1993, p.120) idea of consumption: "Literally, "consumption" means the use of commodities for the satisfaction of needs and desires" (Bocock, 1993).

Giddens (1991) observes that commodification influences the projection of the self and the establishment of lifestyles (Giddens, 1991). He also considers that commodified markers of identity are judged for their symbolic significance. Given this perspective, arguments that these two topics are not related is questionable. Bauman (1987), for instance, speaks of "a culture in which men and women are integrated into society as, above all, consumers." (Engstorm, 2008b). where the logic of market exchange spills over into other domains of life, challenging and undermining alternative modes of distribution, authority, and association. The result, he suggests, is that every item of culture becomes a commodity

\section{RESEARCH CONCEPTUAL FRAMEWORK}

A conceptual framework is a structure that a researcher believes can best explain the natural progression of the phenomenon to be studied [46]. The conceptual framework of this paper is to conduct a literature review of four previously reported scholarly investigations and to integrate their findings to best unveil the agenda hidden in behind the media narrative of a bride, which results in the significant increase of wedding-related purchases (consumption).

The first study was conducted by Parker [47] on the stigmatization of unmarried women. The second investigation pertained to the depictions of spinsters in the media and was undertaken by Chang (Boden, 2001d). Third, Boden (Engstorm, 2008b) conducted a study of the construction of the bridal identity and the institution of the wedding consumer culture. Finally, was Engstrom (2008) examined the hegemonic messages that could be observed in wedding rituals, gender roles, and consumption patterns of modern society (Adoni and Mane, 1984a).

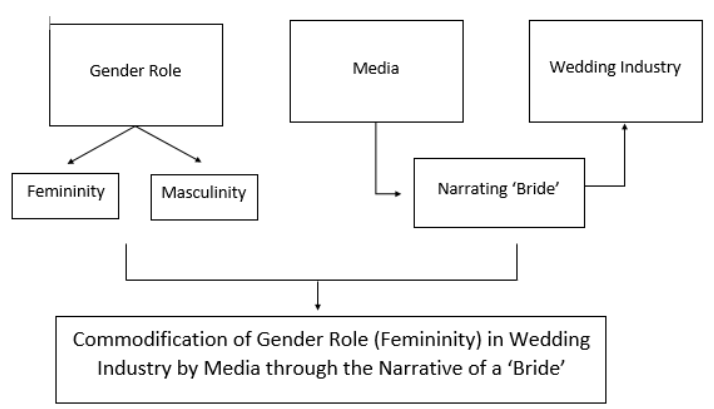

Figure 1 Conceptual Framework.

\section{DO THE CONSTRUCTION AND REPRESENTATION OF WOMEN'S SOCIAL ROLES CAUSE THEIR COMMODIFICATION BY THE WEDDING INDUSTRY?}

According to Adoni (1984) construction is by definition a process that includes interactions among individuals, society, and culture (Bauman, 1987). Heuristically, the process comprises three different realities: objective, symbolic, and subjective. First, objective realities are experienced as the world existing independently and detachedly outside the individual. Objective realities may take a symbolic form through art, literature, or media content. Finally, subjective reality is made from the input of both objective and symbolic realities to build an individual's personal sense of existence (Adoni and Mane, 1984b). 
Nowadays, the significant growth of technologies undeniably expedites interactions among individuals through the Internet. The media sector is considerably reformed through the assistance of technologies that have been integrated significantly into the daily lives of people. Access to segmented media has become exponentially easier. As much as $57 \%$ of the 7.6 Billion global population comprises active Internet users (Hootsuite). Therefore, an oppositional stream of information affects network societies. On the one hand, it becomes easier for the media to target specified individuals to whom a constructed reality is to be presented and for whom they represent certain beliefs, norms, realities, and perceptions to issues that are deemed "important." Conversely, individual opinions, minor social movements, and niche communities also have more freedom to address such matters of gravity (Chatterjee, 2004).

For women, technological development has enhanced the rise of behavioral patterning through modeling (Fulk, 1993a). This statement is supported by Tubella et al. (2003), who claim that the constructions of social and cultural identity in this network society are increasingly built, represented, and promoted by the media through symbolic characters to stimulate levels of emotional involvement that contribute to the viability of individuals (Tubella et al., 2003). Behavioral patterning through modeling is not just about imitation; instead, it involves considerable cognitive processing of stimuli. Thus, the symbolic representation of experiences is a key step in the retention of modeled behavior (Fulk, 1993b). Social information from surroundings for women form provisions of standards for judging the appropriateness of particular behaviors and for appropriately rationalizing certain conducts.

Womanhood, as configured by the media, is imaged in the form of the perfect bride, the white wedding, and the desire to find and marry "the one." This "wedding imaginary" is a heterosexual cultural logic that centers on weddings in media narratives (Winch and Webster, 2012). Walter (2010) adds that this phenomenon is a "new traditionalism," a situation in which the media "sells" a portraiture of womanhood that is reliant in becoming the perfect bride. This traditionalism is then reconfigured by addressing the bride through a rhetoric of self-empowerment which celebrates choice and promises that the possibility of perfection lies in an abundance of branded goods and strategic planning (Walter, 2010).

Women are placed within a marital discourse that has sought to frame them as a potential market for the wedding industry, a source that lies beyond the financial opportunity for wedding-related purchases. According to Mosco (2009), Commodification is the "process of transforming things valued for their use (use value) into marketable products that are valued for what they can bring in exchange (exchange value)" (Mosco, 2009).
Marriage and the media emphasis on the women's perspective have been transformed largely beyond the use value of the wedding as a legal validation of a heterosexual relationship between a man and a woman to its exchange value of placing women within society. Effectively, this placement presents the bride as a commodity. Further support from the wedding media has served to reinforce this commodification and to legitimize the message. In this manner, the media contribute to the processes of commodification of the image of the bride and thus to of the wedding industry, as to many other issues (Benson, 2006).

\section{CONCLUSION: THE COMMODIFICATION OF FEMININITY BY THE WEDDING INDUSTRY}

In sum, the present literature study reveals the existence of an invisible chain of social construction that commodifies femininity through the construction of the image of the bride and the promotion of the wedding industry. This chain seems invisible unless its connections are critically analyzed and the greater picture appears as commonsensical. A long historical process of the institution of patriarchy is included in the chain and the media are positioned at the center of the sequence, securing and assuring the constructed reality through their hegemonic messages on weddings, gender roles, and consumption. In the end, the manner in which the media offer an overview of marriage and the ways in which the media machinery positions women in society implicate beliefs that glorify marriage by emphasizing women's perspectives, which leads to the wedding industry's immense potential to attract capital and to elicit a significant increase of wedding-related consumption.

The feminine ideal generally forwarded by bridal media opposes the wider picture of the social status of women in contemporary society. Research has evidenced how media aggregates such as The Knot (UK's selfproclaimed \#1 bridal media platform) portray strong women who claim to "know what they want" and who have established a successful career of themselves. Yet, these women are still predisposed to take on decidedly feminine roles within the wedding context. For example, Cara, a Wall Street broker who has earned a seat on the New York Stock Exchange, plans and gets her "fairytale" wedding (Boden, 2001d). Such reporting indicates that even a woman like Cara who has carved a niche for herself in the male-dominate world of stockbroking and who seems to promote feminism in by creating equality for herself in her spheres of social life symbolizes the feminine values embodied in the self-image of a beautiful, finely dressed "princess" through the wedding imagery.

Therefore, it may be concluded that femininity is not merely a constructed reality; it can also be deliberately 
marketed as a commodity to fulfill a woman's need to belong to a society. Seen from a larger perspective, the use of women's femininity as a commodity is expected to build an emotional relationship between women as consumers and the glorified image of marriages. Subsequently this association can contribute to women's over-consumptive decisions toward wedding-related expenses so they can meet the mediated and constructed idea of performing according to the "ultimate" portraiture of femininity as narrated by the figure of the bride.

\section{DIRECTIONS FOR FUTURE RESEARCH}

The novel, digital-era commodification of gender roles by the wedding industry can be explored by future research endeavors. The construction of women and marriage through social media in Indonesia could be an interesting topic because $56 \%$ of the total population of Indonesia amounting to 150 million people (Hootsuite (we are social): Indonesian digital report 2019) are social media users. Further, future studies can also examine some major wedding media platforms that use social media and function in crucial ways in the construction of the social representation of women. It would be useful for future researchers to scrutinize the connection between this social representation of women via social media and the promotion of marriage in an effort to amplify the growth of the already $\$ 7$ billion wedding industry in Indonesia (Co, 2017).

\section{REFERENCES}

[1] 'Hootsuite (we are social): Indonesian digital report 2019'. Retrieved from https://andi.link/hootsuite-we-are-socialindonesian-digital-report-2019/.

[2] 'Read about the 'hegemonic' group (the unstigmatized people) are what society projected as 'Normal' and the stigmatized people are the 'minorities' for their characteristic that disqualify them as 'Normal'. Goffman Erving' (1963) Stigma: notes on the management of spoiled identity. New Jersey: Englewood Cliffs.

[3] Adoni, H. and Mane, S. (1984a). 'Media and the social construction of reality: Toward an integration of theory and research'. Communication Research, 11(3), 323-340. https://doi.org/10.1177/009365084011003001.

[4] Adoni, H.. and Mane, S. 1984b Media and the social construction of reality: Towards integration of theory and research.https://doi.org/10.1177/009365084011003 001. University of Jerusalem, Jerusalem.

[5] Bauer, C. and Ritt, L. 1979 Free and ennobled: source reading in the development of Victorian feminism. Pergamon Press, New York.
[6] Bauman, Z. 1987 Legislators and interpreters: on modernity, post-modernity and intellectuals. Polity Press, Cambridge.

[7] Benson, S. J. 2006 Commodification of Asian international students in radio media discourse. Auckland University of Technology, New Zealand.

[8] Bhasin, K. 2006 What is patriarchy. Women Unlimited, New Delhi.

[9] Bocock, R. 1993 Consumption. Routledge, London.

[10] Boden, S. 2001a. 'Superbrides' Wedding consumer culture and the construction of bridal identity. Sociological Research Online, London.

[11] Boden, S. 2001b. 'Superbrides' Wedding consumer culture and the construction of bridal identity 112 . Sociological Research Online, London.

[12] Boden, S. 2001c. 'Superbrides' Wedding consumer culture and the construction of bridal identity 113 Sociological Research Online, London.

[13] Boden, S. 2001d. 'Superbrides' Wedding consumer culture and the construction of bridal identity 78 Sociological Research Online, London.

[14] Brodie, R. 2004. 'Virus of the mind: the new science of the meme'. Retrieved from http://books.google.com/books?id=s6p8lkD5xiIC\& printsec $=$ frontcover $\& d q=$ virus + of + the + mind + richa rd+brodie\#PPA48,M1 described this phenomenon of "culture pressure" using the concept of a meme, which he defined as an "internal representation of knowledge that results in outward effects on the world" (p. 28). Integral Press, Seattle, WA.

[15] Brooks, D. E. and Hébert, L. P. 2006 Gender, race and media representation (chapter 16 of THE SAGE handbook of gender and communication). Sage Publishing, CA.

[16] Bruinessen, M. van (1988). “'Duit, Djodoh, Dukun': Observations on cultural change Among poor migrants to Bandung'. Masyarakat Indonesia, 15 , pp. 35-65.

[17] Camp, W. G. (2001). 'Formulating and Evaluating Theoretical Frameworks for Career and Technical Education Research'. Journal of Vocational Education Research'. Journal of Vocational Educational Research, 26(1), pp. 27-39.

[18] Carragee, K. M. 1993 A critical evaluation of debates examining the [Media Hegemony Thesis]. Western Journal of Communication, 57 (330-348).

[19] Chang, A. W.-1. 2015 A woman alone: the depictions of spinsters in Irish women's short stories. AEDEI, Ireland. 
[20] Chatterjee, A. (2004). 'Globalization, identity, and television networks: community mediation and global responses in multicultural India' Berkeley: Univerity of California.

[21] Co 2017. 'Wedding business in Indonesia reaches \$ 7 billion a year'. Tempo. Retrieved from https://gaya.tempo.co/read/839343/bisnispernikahan-di-indonesia-capai-us7-miliar-pertahun/full\&view=ok.

[22] Cominos, P. T. 1972 M Vicinus (Ed.) "Innocent Femina Sensualis in Unconscious Conflict," suffer and be still: women in the Victorian age. Indiana University Press, Bloomington 168.

[23] Eagly, A. H. and Steffen, V. J. 1984 Gender stereotypes stem From the distribution of women and men Into social roles. Purdue University, IN.

[24] Eliza Warren, E. (1865). 'How I managed my children' London: Houston and wright. Pg.60.

[25] Engstorm, E. 2008 Unraveling the Knot: political economy and cultural hegemony in Wedding media. University of Nevada, Las Vegas.

[26] Engstrom, E. (2008). 'Unraveling the Knot: political economy and cultural hegemony in Wedding media'. Journal of Communication Inquiry. University of Nevada, Las Vegas, 32(1), p. 60-82. https://doi.org/10.1177/0196859907306833.

[27] Engstrom, E. (2008). 'Unraveling the Knot: political economy and cultural hegemony in Wedding media'. Journal of Communication Inquiry. University of Nevada. Procter \& Gamble, Las Vegas, 32(1), p. 60-82. https://doi.org/10.1177/0196859907306833.

[28] Felski, R. 2000 Doing time: feminist theory and postmodern culture. New York University Press, New York.

[29] Fulk, J. (1993a). 'Social construction of communication technology' The Academy of Management Journal. Retrieved from http://www.jstor.org/stable/256641. The Academy of Management, New York.

[30] Fulk, J. 1993b Ibid.

[31] Gibbons, S. (2003, June 4). 'Bridal media promote merchandise, not marriage'. Women's E-News. Retrieved from http://www.wenews.org/article.cfm/dyn/aid/1353/ retrieved.

[32] Giddens, A. 1991 Modernity and self-identity 197. Polity Press, Cambridge.

[33] Gledhill, C. 1991 Stardom: industry of desire. Routledge, London.
[34] Heatwole, A. 2016 Disney girlhood: princess generations and once Upon a time. University of Pennsylvania, IN.

[35] Hootsuite. 'We are social'. Retrieved from https://andi.link/hootsuite-we-are-socialindonesian-digital-report-2019/ Accessed on June 24th 2019 8:42 PM.

[36] 'McQuail' (1983) notions that media plays part in shaping the individual and collective consciousness by organizing and circulating knowledge which people have of their own everyday life and of the more contexts of their life Retrieved from: Adoni, Hana. \& Sherill Mane (1984). Media and The Social Construction of Reality: Towards Integration of Theory and Research. Jerusaem: Adoni, H. and Mane, S. (1984). 'MEDIA AND THE SOCIAL CONSTRUCTION OF REALITY'. Communication Research, 11(3), 323-340. https://doi.org/10.1177/009365084011003001.

[37] Johnson, S. 2018. '12 Types of wedding bouquet'. Retrieved from https://www.fiftyflowers.com/blog/types-ofbouquets-2/ Retrieved.

[38] Jorgensen-Earp 1990 Ibid.

[39] Kosut, M. 2006 An ironic Fad: the commodification and consumption of tattoos. Blackwell Publishing, Inc, New York.

[40] Landy, M. 1994 [Film] Politics, and Gramsci. University of Minnesota Press, Minneapolis, MN.

[41] Long, P. and Wall, T. Ibid.

[42] Mosco, V. 2009 The political economi of communication. SAGE Publication, London.

[43] Otnes, C. C. and Pleck, E. 2003a Cinderella dreams: the allure of the lavish wedding. University of California Press, CA.

[44] Otnes, C. C. and Pleck, E. 2003b Cinderella dreams: the allure of the lavish wedding 53. University of California Press, CA. (2015). Pg. 11.

[46] Parker, L., Riyani, I. and Nolan, B. (2015a). 'The stigmatisation of widows and divorcees (Janda) in Indonesia, and the possibilities for agency'. Routledge Taylor \& Francis Group, Australia, p. 10. https://doi.org/10.1080/13639811.2016.1111677.

[47] Parker, L., Riyani, I. and Nolan, B. (2015b). 'The stigmatisation of widows and divorcees (Janda) in Indonesia, and the possibilities for agency'. Routledge Taylor \& Francis Group, Australia, p. 
18.

https://doi.org/10.1080/13639811.2016.1111677.

[48] Parker, L., Riyani, I. and Nolan, B. 2016a The stigmatisation of widows and divorcees (Janda) in Indonesia, and the possibilities for agency. https://doi.org/10.1080/13639811.2016.1111677. Routledge Taylor \& Francis Group, Australia.

[49] Parker, L., Riyani, I. and Nolan, B. (2016b). 'The stigmatisation of widows and divorcees (Janda) in Indonesia, and the possibilities for agency'. Indonesia and the Malay World. Routledge Taylor \& Francis Group, Australia, 44(128), p. 27-46. https://doi.org/10.1080/13639811.2016.1111677.

[50] Shunatona, B. 2019. ' 8 Gorgeous wedding makeup looks we're obsessed with'. Retrieved from https://www.cosmopolitan.com/stylebeauty/beauty/advice/a6972/gorgeous-weddingmakeup/ Retrieved.

[51] Slonim, G. 'Nurit GUR-YAISH and Ruth KATZ' (2015). By Choice Or By Circumstance? Stereotypes of and Feelings About Single People. The University of Haifa, Haifa, Israel.
[52] Stonim, G. and Gur-Yaish, N. 2015 By choice or by circumstance? stereotypes of and feelings About single people. The University of Haifa, Haifa.

[53] 2015 Ibid.

[54] Sultana, A. 2011a Patriarchy and women's subordination: A theoretical analysis 3. University of Dhaka. Procter \& Gamble, Bangladesh.

[55] Sultana, A. 2011b Patriarchy and women's subordination: A theoretical analysis. University of Dhaka, Bangladesh.

[56] Tubella, I., Sancho, T., de Isla, D., Isabel, M. and Wellman, B. 2003, [Series Rosa dels Vents with Edicions UOC] La societat xarxa a Catalunya. Random House/Mondadori, Barcelona.

[57] Walter, N. 2010 Living Dolls: the return of sexism. Virago, London.

[58] Winch, A. and Webster, A. 2012 Here comes the brand: wedding media and the management of transformation. Routledge Taylor \& Francis Group, London.

[59] Zoonen, L. Van 1994 Feminist Media Studies (Media Culture \& Society series). SAGE Publication, London. 